\title{
INNOVATION AS ELEMENT OF SOCIAL AND CULTURAL DEVELOPMENT
}

\section{Lesia Turchak ${ }^{1}$}

DOI: https://doi.org/10.30525/978-9934-26-050-6-65

At present, social development in the country depends on many factors, including economic, political, scientific and others. Therefore the term innovation is observed in different areas of life: culture, art, science, economics etc., and this tendency is typical not only for Ukraine.

Today, innovation is defined as an important factor influencing not only the success of a separate organization but the country's socio-economic development on the whole. The notion innovation means positive changes in various spheres of life, it makes it possible to implement new knowledge in everyday practices [2].

Encyclopædia Britannica, a British and American universal encyclopedia, gives the following definition of innovation: «The creation of a new way of

\footnotetext{
${ }^{1}$ Kyiv National University of Culture and Arts, Ukraine
} 
doing something, whether the enterprise is concrete (e.g., the development of a new product) or abstract (e.g., the development of a new philosophy or theoretical approach to a problem).

Innovation plays a key role in the development of sustainable methods of both production and living because in both cases it may be necessary to create alternatives to conventional ways of doing things that were developed before environmental consideration was central to most people's framework for making decisions [6]».

The question of innovation is interesting to many researchers, ranging from economists to artists. Innovation has become not only the source of economic growth and index of social development but also a way of interaction between science and the social sphere, culture and art.

The Law of Ukraine on Innovation Activity defines innovation as follows: newly created (applied) and/or improved competitive technologies, products or services as well as organizational and technical solutions of manufacturing, administrative, commercial or other nature that considerably improve the structure and quality of production and/ or social sphere [5].

One should not forget about the cultural sector the development of which under the modern circumstances depends on the use of innovations. Let's consider some of its special features. The innovation culture is the area of general cultural process characterized by the level of perception by an individual, group of individuals and society of different novelties ranging from tolerance to readiness and ability to transform them into innovation [4].

The innovation culture is a form of culture common to mankind, a new historical reality created by the conscious aspiration of the society for material and spiritual renewal. It serves as a precondition and basis for progress and harmonization of the society's activities [4].

The term innovation is closely related to the notions novelty, invention and discovery. Such notions imply suggesting new ideas, and the distinctive feature of innovations is their embodiment in practice [3].

Such views are confirmed in the research of Bettina von Stamm, $\mathrm{PhD}$ of London Business School, author of Managing Innovation, Design and Creativity. She notes that «art and innovation are often interchangeable. However, there are fundamental differences - creativeness is an important element of innovation. It is reflected in a widely used notion of innovation that equals creativeness plus introduction (innovation $=$ creativeness + successful introduction). Creativeness alone is not enough for idea inception [2]».

The modern processes taking place in the society allow combining creative ideas with new technologies. Thus, during the lockdown period in 2020, museums had to cancel the announced events and refuse from traditional visits and switch to remote operation. Viewers could virtually visit world museums 
including famous institutions of the USA, France, Great Britain, Italy, Austria, Spain, Germany, New Zeeland, Japan, Korea and others.

Virtual galleries, exhibition halls became the alternative option for artists, since such methods of showing your works widen the borders and the circle of viewers.

A great part of artists transform into virtual reality users. Thanks to the Internet, they communicate with the whole world, find partners for exhibitions in virtual exposition halls. They are their own curators, organizers and managers [1, p. 57].

The presentation and visiting of theatrical performances has also changed, which is confirmed by HD Theater project broadcasting the plays of internationally renowned theaters on TV screens. Royal Shakespeare Theatre demonstrated The Tempest, the play by William Shakespeare, in this format. Thus, the British theater has made its audience a thousand times larder: approximately 136,000 people enjoyed The Tempest in Stratford, London; 27,000 students watched the broadcast in their classrooms; and over 95,000 people watched it in the cinema in 17 countries. The coverage in social media reached 6.3 million views, video - 9.8 million views [2].

So cultural projects today are increasingly connected with new technologies. Innovations have become an important factor for both economics and art development.

\section{References:}

1. Avramenko O. (2003) Pro dejaki osoblyvosti funkcionuvannja obrazotvorchogho mystectva v Ukrajini u 1990-ti roky [On Some Special Features of Functioning of Visual Arts in Ukraine in the 1990s]. Art Criticism of Ukraine. Kyiv, edition 3, pp. 56-60. (in Ukrainian)

2. Innovacija jak stylj zhyttja u XXI stolitti. Ukrajinsjkyj kuljturnyj fond. [Innovation as Lifestyle in the $21^{\text {st }}$ Century]. Ukrainian Cultural Foundation (2019). Retrieved from: https://uaculture.org/texts/innovacziya-yak-styl-zhyttya-u-hhi-stolitti/ (accessed 05 March 2021).

3. Lebedeva N.M., Yasin E.G. (2009) Kul'tura i innovatsii: k postanovke problemy [Culture and Innovation: Problem Formulation]. Foresight. Moscow, no. 2, pp. 16-26.

4. Lisin B.K.(2008) Innovatsionnaya kul'tura [Innovation Culture]. Innovation, no. 10, pp. 49-53. Retrieved from: https://cyberleninka.ru/article/n/innovatsionnayakultura/viewer (accessed 05 March 2021).

5. Pro innovacijnu dijaljnistj: Zakon Ukrajiny vid 2002, № 36, st. 266 Redakcija vid 05.12.2012 [On Innovation Activity: Law of Ukraine as of 2002, No. 36, Article 266. Edition as of 05.12.2012]. Retrieved from: https://zakon.rada.gov.ua/laws/show/4015\#Text (accessed 06 March 2021).

6. Sarah E. Boslaugh. Innovation creativity. Britannika. Article. Retrieved from: https://www.britannica.com/topic/in 